\title{
BREAST CANCER IN WESTERN KAZAKHSTAN: INCIDENCE, MORTALITY AND FACTORS ASSOCIATED WITH SURVIVAL
}

\author{
${ }^{1}$ M. A. Aitmagambetova, ${ }^{2}$ Y. Zh. Bekmukhambetov, ${ }^{1}$ G. A. Smagulova, ${ }^{1}$ A. B. Tulyayeva,
}

${ }^{1}$ A. K. Koyshybaev, ${ }^{1,3,4,5}$ A. M. Grjibovski

\begin{abstract}
${ }^{1}$ Marat Ospanov West Kazakhstan Medical University, Aktobe, Kazakhstan; ${ }^{2}$ Association of Individual Entrepreneurs and Legal Entities "National Chamber of Health", Nur-Sultan, Kazakhstan; ${ }^{3}$ Northern State Medical University, Arkhangelsk,

Russia; ${ }^{4}$ North-Eastern Federal University, Yakutsk, Russia; ${ }^{5} \mathrm{Al}$ Farabi Kazakh National University, Almaty, Kazakhstan
\end{abstract}

Background: Breast cancer is the most common cancer among women. Incidence of and mortality from breast cancer varies considerably between countries. The evidence from Kazakhstan, however, is almost non-existent in international peer-reviewed literature.

Aim: To study incidence of and mortality from breast cancer in Western Kazakhstan and assesse selected determinants of survival among breast cancer patients.

Methods: A registry-based historical cohort study. Data on all primary cases of breast cancer in the Aktobe region in 2014-2018 and their follow-up data were obtained from the regional cancer registry. Standardized incidence and mortality data were calculated using Segi world reference population. One- and five-years survival was calculated using actuarial analysis. Factors associated with survival were assessed using multivariable Cox regression. Crude and adjusted hazard ratios (HR) were calculated with $95 \%$ confidence intervals (CI). Results: From 2014 to 2018, 891 new cases and 251 deaths from breast cancer were registered in the Aktobe region. Standardized incidence of breast cancer increased from 40.8 to 44.6 per 100,000 while standardized mortality decreased from 12.4 to 8.8 per 100,000 during the study period. Only $16.4 \%$ of cases were diagnosed at stage I, while $21.6 \%$ of cancer cases were detected at stage III or IV. One- and five-year survival estimates based on the registry data was $94.5 \%$ (95\% CI: $92.5-96.5)$ and $90.2 \%$ (95\% CI: 88.2-92.2), respectively. Patients with stage III (HR $=7.4,95 \%$ CI: 1.7-31.6) and stage IV (HR = 29.7, $95 \%$ CI: 6.7-131.8) had shorter survival than patients with stage I.

Conclusions: Both incidence and mortality of breast cancer in Western Kazakhstan are lower than in most European countries. The incidence has been gradually increasing while no clear pattern on mortality was observed. Surprisingly high level of five-year survival in the study area requires further investigation. The results should be interpreted with caution assuming valid data on cancer-specific mortality and non-differential reporting of deaths across the studied characteristics.

Key words: breast cancer, incidence, mortality, survival, Kazakhstan

УДК 618.19-006.(574)

DOI: 1033396/1728-0869-2021-7-51-57

\section{РАК МОЛОЧНОЙ ЖЕЛЕЗЫ В ЗАПАДНОМ КАЗАХСТАНЕ: ЗАБОЛЕВАЕМОСТЬ, СМЕРТНОСТЬ И ФАКТОРЫ, ВЛИЯЮЩИЕ НА ВЫЖИВАЕМОСТЬ}

\section{() 2021 г. ${ }^{1}$ М. А. Айтмагамбетова, ${ }^{2}$ Е. Ж. Бекмухамбетов, ${ }^{1}$ Г. А. Смагулова, ${ }^{1}$ А. Б. Туляева, ${ }^{1}$ А. К. Койшибаев, ${ }^{1,3,4,5}$ А. М. Гржибовский}

\author{
${ }^{1}$ Западно-Казахстанский медицинский университет им. Марата Оспанова, г. Актобе, Казахстан; ${ }^{206 ъ е д и н е н и е ~}$ \\ Индивидуальных Предпринимателей и Юридических лиц «Национальная Палата Здравоохранения», г. Нур-Султан, \\ Казахстан; ${ }^{3}$ Северный государственный медицинский университет, г. Архангельск, Россия; “ \\ федеральный университет, г. Якутск, Россия; ${ }^{5 К а з а х с к и и ̆ ~ н а ц и о н а л ь н ы и ̆ ~ у н и в е р с и т е т ~ и м . ~ А л ь-Ф а р а б и, ~ г . ~ А л м а т ы, ~ К а з а х с т а н ~}$
}

Введение: Рак молочной железы (РМЖ) является самым распространенным злокачественным новообразованием у женщин. Заболеваемость РМЖ и смертность от него сильно различаются в разных странах, однако сведения из Казахстана по данной теме по-прежнему редко встречаются в международной рецензируемой литературе.

Цель: изучить заболеваемость и смертность от РМЖ в Западном Казахстане и оценить влияние ряда факторов на выживаемость пациентов.

Методы: Данные о всех первичных случаях РМЖ за период 2014-2018 гг. получены из Западно-Казахстанского онкологического регистра в Актюбинской области. Расчет стандартизованных показателей заболеваемости и смертности проводили с использованием референтной мировой популяции Segi. Однолетняя и пятилетняя выживаемость рассчитывались с помощью актуарного анализа. Факторы, влияющие на выживаемость, изучали с помощью многомерного анализа пропорциональных рисков Кокса с расчетом нескорректированных и скорректированных относительных рисков (HR) с 95 \% доверительными интервалами (ДИ).

Результаты: За период с 2014 по 2018 г. зарегистрирован 891 новый случай РМЖ и 251 летальный исход от РМЖ в Актюбинской области. Стандартизованная заболеваемость РМЖ увеличилась с 40,8 до 44,6 на 100000 населения, в то время как смертность от РМЖ снизилась от 12,4 до 8,8 на 100000 населения за изучаемый период. Только 16,4 \% случаев были диагностированы на I стадии. На стадиях III и IV зарегистрированы 21,6 \% случаев. Одно- и пятилетняя выживаемость по данным регистра составили 94,5 (95 \% ДИ: 92,5-96,5) \% и 90,2 (95\% ДИ: 88,2-92,2) \% соответственно. Только стадии болезни III (HR = 7,4, 95 \% ДИ: 1,7-31,6) и IV (HR $=29,7,95 \%$ ДИ: 6,7-131,8) на момент постановки диагноза были значимо связаны с повышенным риском более раннего летального исхода. 


\begin{abstract}
Выводы: Заболеваемость РМЖ в Западном Казахстане увеличивается, но она все еще значительно ниже, чем в большинстве стран Европейского региона В03. Смертность от РМЖ снижается и находится несколько ниже, чем в большинстве европейских стран. Высокая пятилетняя выживаемость нуждается в более детальном изучении причин. Результаты исследования следует интерпретировать с осторожностью при допущении достаточной валидности данных и отсутствии дифференциальных систематических ошибок в оценке смертности относительно изучаемых факторных признаков.

Ключевые слова: рак молочной железы, заболеваемость, смертность, выживаемость, Казахстан
\end{abstract}

For citing:

Aitmagambetova M. A., Bekmukhambetov Y. Zh., Smagulova G. A., Tulyayeva A. B., Koyshybaev A. K., Grjibovski A. M. Breast Cancer in Western Kazakhstan: Incidence, Mortality and Factors Associated with Survival. Ekologiya cheloveka (Human Ecology). 2021,7, pp. $51-57$.

Библиографическая ссылка:

Айтмагамбетова М. А., Бекмухамбетов Е. Ж., Смагулова Г. А., Туляева А. Б., Койшибаев А. К., Гржибовский А. М. Рак молочной железы в Западном Казахстане: заболеваемость, смертность и факторы, влияющие на выживаемость // Экология человека. 2021. № 7. C. 51-57.

\section{Introduction}

Breast cancer is the most common cancer among women in most countries around the world, accounting for a quarter of all cancers diagnosed in women [11]. It is substantial public health and medical problem because of high mortality rates worldwide [22]. In 2018, 18.1 million new cases and 9.6 million deaths from breast cancer were registered worldwide, and on average, the risk of developing cancer before the age of 75 was estimated to be about $20 \%$ [12]. At the same time, the incidence of breast cancer varies considerably [8]. Almost $60 \%$ of all cancer cases occur in developing countries [27]. Based on the GLOBOCAN 2018 data, an estimated age-standardized incidence rate (ASR) for breast cancer among women showed high rates in Australia and Western Europe (94.2 and 96.4 per 100,000, respectively), while the lowest rates were recorded in South-East Asia, Central Africa and South-Central Asia (38.1, 27.9 and 25.9 per 100,000, respectively) [25].

According to GLOBOCAN, the global mortality form breast cancer in 2018 was 13 per 100,000 population. The highest mortality was recorded in Melanesia - 25.5 per 100,000, in East Africa - 15.8 per 100,000 and Central Asia - 14.1 per 100,000. At the same time, mortality in East Asia was 8.6 per 100,000 [25].

According to the CONCORD Global Cancer Survival Surveillance Program, the five-year breast cancer survival ranges from approximately $90 \%$ in the US and Australia to $40 \%$ in South Africa [3]. In Asia, high five-year survival was observed in Israel $(88 \%)$ and Japan ( $85 \%$ ) while the lowest survival was registered in India $(66.1 \%)$ [3].

Several studies have reported an increase in the incidence of breast cancer in Kazakhstan [6, 11, 15, 24]. The latest data suggest that the age-standardized incidence of breast cancer is 37.2 per 100,000 while cause-specific mortality is 14.8 per 100000 [25]. However, national data can mask regional variations, particularly in large countries as Kazakhstan. An electronic cancer registry (ECR) at the Medical Center of the West Kazakhstan Medical University contains data on all breast cancer cases that occur in the Aktobe region, Western Kazakhstan providing opportunities for epidemiological studies.
The aim of this paper was to present internationally comparable data on the incidence of and mortality from breast cancer, one- and five-years survival and to study factors associated with survival of breast cancer patients in Western Kazakhstan.

\section{Methods}

This is a historical registry-based cohort study. We used data on all breast cancer cases that occurred from 2014-2018 in the Aktobe region, Western Kazakhstan, and were recorded in the registry. For the purpose of this study we extracted information on date of birth, date of diagnosis of cancer, date of death or censoring, place of residence, ethnic background, social status, morphological type of tumor and stage of cancer. Data on population size of the Aktobe region for calculating incidence of and mortality from breast cancer was obtained from the regional statistical office.

Age at diagnosis was calculated using date of birth and date of diagnosis and was classified as 20-39, 40-49, 50-59, 60-69 and 70+ years. By ethnicity all patients were dichotomized into Kazakhs and others. Socioeconomic status of the patients was coded as employed, unemployed and pensioners. Place of residence was dichotomized into urban and rural. By morphological type the following categories were used: ductal carcinoma, lobular carcinoma, and other. By stage at the moment of diagnosis the cases were coded using the TNM staging and coded from I to IV.

Standardized incidence and cause-specific mortality rates were calculated using Segi world 2000-2025 standard population. One- and five-years overall cause-specific survival was calculated using life-tables method and presented with $95 \%$ confidence intervals (CI). Associations between independent variables and the outcome were assessed using multivariable Cox regression. Crude and adjusted hazard ratios (HRs) were calculated and presented with $95 \%$ CI. Agegroups 20-29 and 30-39 years were merged into one group in survival analysis because of low number of cases in the former. Cases diagnosed at autopsy and were excluded from survival analysis. All calculations were performed using Stata software, version 15.0 (StataCorp, TX, USA) [2].

The study was approved be the ethical committee of 
the Marat Ospanov West Kazakhstan Medical University (Protocol \#24 from 3 October 2017).

\section{Results}

In total, 891 new cases and 63 deaths from breast cancer were registered from 2014 to 2018 in the Aktobe region. Most of the new cases $(30.1 \%)$ and deaths $(41.3 \%)$ occurred in the age-group 50-59 years. The lowest proportions of cases $(9.2 \%)$ and deaths (9.5\%) were registered in the youngest age-group. Only $16.4 \%$ of cases were diagnosed at stage I while $21.6 \%$ of cancers had stage III or IV at the time of diagnosis. By histological type, most breast cancers were ductal carcinomas constituting more than fourth fifths of all cases. Detailed information about new cases is presented in Table 1.

Crude incidence of breast cancer increased from 41.6 to 45.6 per 100000 while age-standardized incidence increased from 40.8 to 44.6 per 100,000 during the study period (Figure 1). Proportions of newly diagnosed cases considerably increased among 60-69 years old women while the proportion of new cases in age groups 40 $49,50-59$ and $70+$ decreased over the years. Detailed information on the number of cases and incidence as well as the proportion of new cases in all age groups is given in Table 2 .

Crude death rates from breast cancer increased from 11.2 in 2014 to 14.0 per 100000 in 2017, but then decreased to 9.0 per 100000 in 2018 . The proportion of deaths increased from 0 to $5 \%$ among the youngest women while the proportion of deaths among women aged 60 years or older has been decreasing. Almost one third of deaths in 2018 occurred in age-group 40-49 years (Table 3). Age-standardized mortality decreased from 12.4 per 100,000 to 8.8 per 100,000 during the study period (Figure 1).

One- and five-years survival during the study period was $94.5 \%$ (95\% CI: 92.5-96.5) and $90.2 \%$ (95\% CI: 88.2-92.2), respectively. Detailed information on one- and five-years cancer-specific survival across all independent variables is presented in Table 1.

In crude analysis, all variables except ethic background and place of residence were significantly associated with survival. In multivariable analysis all associations except the one for the stage of cancer were reduced to nonsignificant levels. We observed a clear inverse association

Number of new cases of and deaths from breast cancer, one- and five-year cancer-specific survival (CSS)

Table 1 with $95 \%$ confidence intervals (CI) in 2014-2018 in the Aktobe region, Western Kazakhstan

\begin{tabular}{|c|c|c|c|c|}
\hline Characteristic & $\mathrm{N}(\%)$ cases & $\mathrm{N}(\%)$ deaths & One-year CSS (95% CI) & Five-year CSS $(95 \%$ CI $)$ \\
\hline \multicolumn{5}{|l|}{ Age, years } \\
\hline $20-39$ & $82(9.2)$ & $6(9.5)$ & $0.96(0.92-1.00)$ & $0.88(0.78-0.98)$ \\
\hline $40-49$ & $207(23.2)$ & $8(12.7)$ & $0.97(0.95-0.99)$ & $0.95(0.91-0.99)$ \\
\hline $50-59$ & $268(30.1)$ & $26(41.3)$ & $0.93(0.89-0.97)$ & $0.87(0.83-0.91)$ \\
\hline $60-69$ & $214(24.0)$ & $10(15.9)$ & $0.96(0.94-0.98)$ & $0.93(0.89-0.97)$ \\
\hline $70+$ & $120(13.5)$ & $13(20.6)$ & $0.90(0.84-0.96)$ & $0.85(0.77-0.93)$ \\
\hline \multicolumn{5}{|l|}{ Ethnic background } \\
\hline Kazakh & $551(61.8)$ & $40(63.5)$ & $0.95(0.93-0.97)$ & $0.90(0.86-0.94)$ \\
\hline Other & $340(38.2)$ & $23(36.5)$ & $0.94(0.92-0.96)$ & $0.91(0.87-0.95)$ \\
\hline \multicolumn{5}{|l|}{ Employment status } \\
\hline Pensioner & $342(38.4)$ & $25(39.7)$ & $0.93(0.91-0.95)$ & $0.90(0.86-0.94)$ \\
\hline Unemployed & $157(17.6)$ & $20(31.7)$ & $0.90(0.84-0.86)$ & $0.84(0.78-0.90)$ \\
\hline Employed & $392(44.0)$ & $18(28.6)$ & $0.97(0.95-0.99)$ & $0.93(0.89-0.97)$ \\
\hline \multicolumn{5}{|l|}{ Place of residence } \\
\hline Urban & $602(67.6)$ & $43(68.3)$ & $0.94(0.92-0.96)$ & $0.90(0.88-0.92)$ \\
\hline Rural & $289(32.4)$ & $20(31.7)$ & $0.95(0.93-0.97)$ & $0.90(0.86-0.94)$ \\
\hline \multicolumn{5}{|l|}{ Histological type } \\
\hline Ductal carcinoma & $720(80.8)$ & $47(74.6)$ & $0.95(0.93-0.97)$ & $0.91(0.89-0.93)$ \\
\hline Lobular carcinoma & $48(5.4)$ & $2(3.2)$ & $0.95(0.89-1.00)$ & $0.95(0.89-1.00)$ \\
\hline Other types & $123(13.8)$ & $14(22.2)$ & $0.89(0.83-0.95)$ & $0.85(0.77-0.93)$ \\
\hline \multicolumn{5}{|l|}{ Stage } \\
\hline I & $146(16.4)$ & $2(3.2)$ & $0.99(0.97-1.00)$ & $0.98(0.96-1.00)$ \\
\hline II & $553(62.1)$ & $22(34.9)$ & $0.98(0.96-1.00)$ & $0.94(0.92-0.96)$ \\
\hline III & $147(16.5)$ & $21(33.3)$ & $0.91(0.87-0.95)$ & $0.83(0.77-0.89)$ \\
\hline IV & $45(5.1)$ & $18(28.6)$ & $0.56(0.40-0.72)$ & $0.52(0.36-0.68)$ \\
\hline
\end{tabular}


Absolute number of new cases of breast cancer $(\mathrm{N})$, incidence rates (I) and proportion of all cases (\%)

Table 2 across-age groups in 2014-2018 in the Aktobe region, Western Kazakhstan

\begin{tabular}{|c|c|c|c|c|c|c|c|c|c|c|c|c|c|c|c|c|c|c|}
\hline Year & \multicolumn{3}{|c|}{ 20-39 years } & \multicolumn{3}{|c|}{ 40-49 years } & \multicolumn{3}{|c|}{$50-59$ years } & \multicolumn{3}{|c|}{$60-69$ years } & \multicolumn{3}{|c|}{$70+$ years } & \multicolumn{3}{|c|}{ Total } \\
\hline & $\mathrm{N}$ & I & $\%$ & $\mathrm{~N}$ & I & $\%$ & $\mathrm{~N}$ & I & $\%$ & $\mathrm{~N}$ & I & $\%$ & $\mathrm{~N}$ & I & $\%$ & $\mathrm{~N}$ & I & $\%$ \\
\hline 2014 & 15 & 10.5 & 8.6 & 44 & 80.5 & 25.3 & 58 & 121.8 & 33.3 & 34 & 141.8 & 19.5 & 23 & 106.4 & 13.2 & 174 & 41.6 & 100,0 \\
\hline 2015 & 11 & 7.6 & 6.8 & 47 & 86.3 & 29.2 & 47 & 95.8 & 29.2 & 34 & 127.8 & 21.1 & 22 & 104.9 & 13.7 & 161 & 37.9 & 100,0 \\
\hline 2016 & 26 & 18.1 & 15.6 & 27 & 49.7 & 16.2 & 54 & 106.9 & 32.3 & 43 & 148.2 & 25.8 & 17 & 83.0 & 10.2 & 167 & 38.7 & 100,0 \\
\hline 2017 & 12 & 8.4 & 6.4 & 43 & 79.3 & 23.0 & 55 & 106.6 & 29.4 & 44 & 143.6 & 23.5 & 33 & 159.4 & 17.7 & 187 & 42.8 & 100,0 \\
\hline 2018 & 18 & 12.7 & 8.9 & 46 & 84.7 & 22.8 & 54 & 103.8 & 26.7 & 59 & 183.0 & 29.2 & 25 & 116.5 & 12.4 & 202 & 45.6 & 100,0 \\
\hline
\end{tabular}

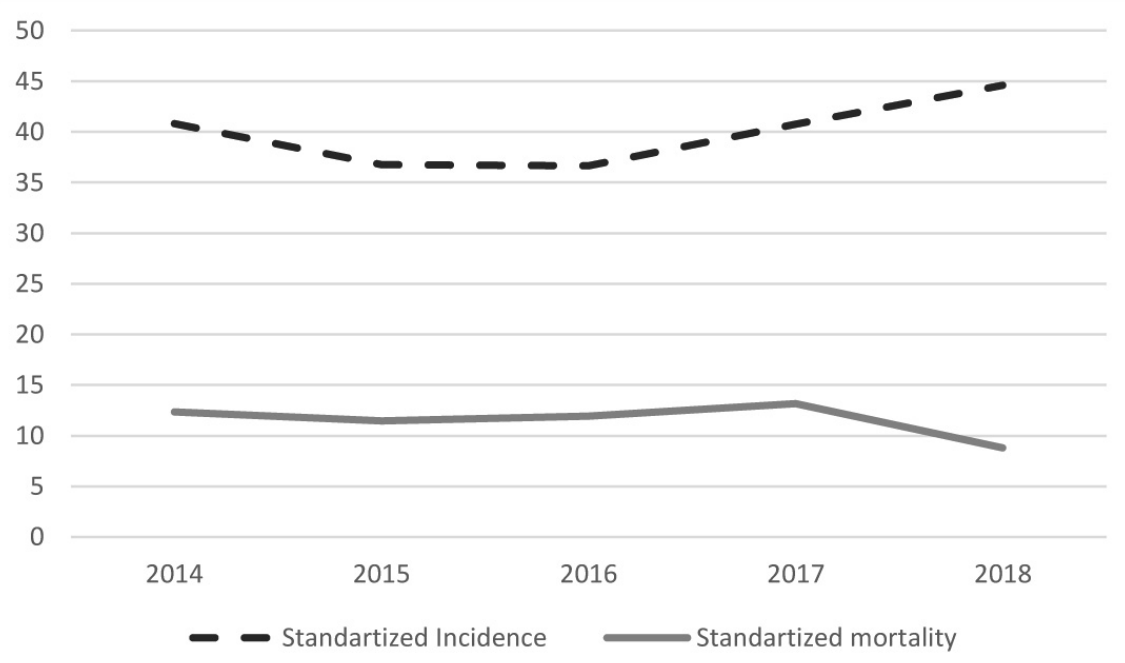

Standardized incidence of and mortality from breast cancer in Western Kazakhstan in 2014-2018

between survival and the stage of cancer ( $\mathrm{p}$ for trend $<0.001)$. Crude and adjusted HRs for all independent variables are presented in Table 4.

\section{Discussion}

This is one of the first studies presenting internationally comparable data on the epidemiology and survival of breast cancer in West Kazakhstan in 2014-2018. The main advantage of the study is the use of registry data collected using standardized methodology [14]. The ECR contains data on all registered cases of cancer in the Aktobe region since 2013. The main limitation is that ECR does not contain information on socio-economic status, parity, genetic- and other factors that are known to be associated with breast cancer survival.
The main results show that crude incidence of breast cancer has increased during the study period while mortality has decreased. Earlier studies from the same region have reported that breast cancer mortality increased from 1980 through 2009 [5, 17]. Our findings indicate that this long-term trend has reversed which can at least partly be explained by improvement in early detection of breast cancer and improved treatment of the disease in Western Kazakhstan. Whether this trend is shared by other regions and on the national level remains to be studied.

The incidence of breast cancer is increasing in most settings all over the world, but the most pronounced increase has been observed in developing countries [26]. Although the incidence in Asian countries is

Absolute number of deaths from breast cancer $(\mathrm{N})$, mortality rates $(M)$ and proportion of all cases (\%)

Table 3 across-age groups in 2014-2018 in the Aktobe region, Western Kazakhstan

\begin{tabular}{|c|c|c|c|c|c|c|c|c|c|c|c|c|c|c|c|c|c|c|}
\hline \multirow[t]{2}{*}{ Year } & \multicolumn{3}{|c|}{$20-39$ years } & \multicolumn{3}{|c|}{$40-49$ years } & \multicolumn{3}{|c|}{$50-59$ years } & \multicolumn{3}{|c|}{$60-69$ years } & \multicolumn{3}{|c|}{$70+$ years } & \multicolumn{3}{|c|}{ Total } \\
\hline & $\mathrm{N}$ & M & $\%$ & $\mathrm{~N}$ & M & $\%$ & $\mathrm{~N}$ & M & $\%$ & $\mathrm{~N}$ & $M$ & $\%$ & $\mathrm{~N}$ & $M$ & $\%$ & $\mathrm{~N}$ & $M$ & $\%$ \\
\hline 2014 & 0 & 0.0 & 0.0 & 4 & 7.3 & 8.5 & 11 & 23.1 & 23.4 & 18 & 75.1 & 38.3 & 14 & 64.8 & 29.8 & 47 & 11.2 & 100,0 \\
\hline 2015 & 0 & 0.0 & 0.0 & 3 & 5.5 & 6.1 & 15 & 30.6 & 30.6 & 15 & 56.4 & 30.6 & 16 & 76.3 & 32.7 & 49 & 11.5 & 100,0 \\
\hline 2016 & 3 & 2.1 & 5.5 & 4 & 7.4 & 7.4 & 17 & 33.6 & 31.5 & 14 & 48.3 & 25.9 & 16 & 78.1 & 29.6 & 54 & 12.5 & 100,0 \\
\hline 2017 & 7 & 4.9 & 11.5 & 3 & 5.5 & 4.9 & 22 & 42.6 & 36.1 & 18 & 58.7 & 29.5 & 11 & 53.1 & 18.0 & 61 & 14.0 & 100,0 \\
\hline 2018 & 2 & 1.4 & 5.0 & 12 & 22.1 & 30.0 & 9 & 17.3 & 22.5 & 7 & 21.7 & 17.5 & 10 & 46.6 & 25.0 & 40 & 9.0 & 100,0 \\
\hline
\end{tabular}


Crude and adjusted hazard ratios (HR) with $95 \%$ confidence intervals $(\mathrm{CI})$ for cancer-specific survival of patients with breast cancer in 2014-2018 in the Aktobe region, Western Kazakhstan

\begin{tabular}{|c|c|c|c|c|c|c|}
\hline Characteristic & Crude HR & $95 \% \mathrm{CI}$ & $\mathrm{P}$ & Adjusted HR* & $95 \% \mathrm{CI}$ & $\mathrm{P}$ \\
\hline Age, years & & & 0.043 & & & 0.353 \\
\hline 20-39 & 1.00 & Reference & & 1.00 & Reference & \\
\hline $40-49$ & 0.52 & $0.18-1.51$ & & 0.54 & $0.18-1.58$ & \\
\hline $50-59$ & 1.34 & $0.55-3.25$ & & 1.08 & $0.43-2.76$ & \\
\hline $60-69$ & 0.69 & $0.25-1.90$ & & 0.63 & $1.56-2.53$ & \\
\hline $70+$ & 1.66 & $0.62-4.36$ & & 1.06 & $0.25-4.48$ & \\
\hline Ethnic background & & & 0.707 & & & 0.565 \\
\hline Kazakh & 1.00 & Reference & & 1.00 & Reference & \\
\hline Other & 1.10 & $0.66-1.84$ & & 0.85 & $0.49-1.47$ & \\
\hline Employment status & & & 0.008 & & & 0.146 \\
\hline Pensioner & 1.76 & $0.96-3.22$ & & 1.64 & $0.56-4.69$ & \\
\hline Unemployed & 2.73 & $1.45-5.17$ & & 1.90 & $0.98-3.69$ & \\
\hline Employed & 1.00 & Reference & & 1.00 & Reference & \\
\hline Place of residence & & & 0.981 & & & 0.802 \\
\hline Urban & 1.01 & $0.59-1.71$ & & 1.07 & $0.62-1.86$ & \\
\hline Rural & 1.00 & Reference & & 1.00 & Reference & \\
\hline Morphology & & & 0.025 & & & 0.445 \\
\hline Ductal carcinoma & 1.00 & Reference & & 1.00 & Reference & \\
\hline Lobular carcinoma & 0.61 & $0.15-2.51$ & & 0.96 & $0.23-4.03$ & \\
\hline Other types & 2.14 & $1.20-3.95$ & & 1.50 & $0.80-2.81$ & \\
\hline Stage & & & $<0.001$ & & & $<0.001$ \\
\hline I & 1.00 & Reference & & 1.00 & Reference & \\
\hline II & 2.31 & $0.54-9.81$ & & 2.44 & $0.57-10.5$ & \\
\hline III & 8.05 & $1.89-34.3$ & & 7.35 & $1.71-31.6$ & \\
\hline IV & 39.2 & $9.10-169.1$ & & 29.7 & $6.70-131.8$ & \\
\hline
\end{tabular}

*Adjusted for the variables in the table.

lower than in Europe and the Americas, the increase in breast cancer deaths in Asia is substantial compared to European and American countries ranging from 6 to 23 per $100,000[10,24]$. A substantial volume of literature supports the view that the recent increase in the incidence of breast cancer among women in Asia is due to the economic development and adopting Western lifestyle including delayed childbirth, reduction in parity, shortening of breastfeeding duration, weight gain and an increase in consumption of animal fat and other carcinogenic food items $[7,20]$.

One of the most striking results of this study was a five-year survival of $90.2 \%$ which is comparable to the most recent data from the US or Australia. Given that the five-year survival of breast cancer patients in Russia and Belarus - countries similar to Kazakhstan in many respects - is below $80 \%$ one should also consider alternative explanations of the findings. Validity of the data is crucial in epidemiological studies. High survival in this study may reflect the real world scenario given that Western Kazakhstan is a relatively affluent part of the country with better-then-average level of medical services. However, an alternative scenario with insufficient communication between ECR and regional statistical services that might cause underestimation of breast cancer deaths and overestimation of survival should be considered as a more likely scienario. The authors could not trace each case of breast cancer, but future research should assess completeness of ECR and validity of the mortality data. Another issue related to the validity of the data is differential reporting of mortality that may threaten the validity of the results presented in Table 4. Although given high survival rates may raise concerns about potential overestimation, it is unlikely that reporting of mortality is differential across the independent variables used in this study.

In 2008, a national breast cancer screening program was introduced in Kazakhstan. Women aged 50 years or older undergo double-reading mammography every second year. This has contributed to the increase in the incidence of breast cancer. However, due to an increase in the number of cases among young women this age limit was shifted to 40 years [1]. Breast cancer is the most commonly diagnosed cancer among Kazakhstani women and mortality from breast cancer in Kazakhstan is the highest in Central Asia. As many as $17.3 \%$ 
of all cancer deaths were attributed to breast cancer. Very high mortality rates are registered in women who were diagnosed at late stages of cancer [4, 9, 28]. Large variations in both the incidence and mortality from breast cancer have been observed between the regions of Kazakhstan. Nur-Sultan, Almaty, and the four central and eastern regions of Kazakhstan have been reported to have the highest mortality from breast cancer [6]. Recent studies have shown some decrease in mortality from breast cancer in large cities of Kazakhstan in parallel with an increase in proportion of cancers diagnosed at early stages [16]. However, this success has not been universal across the country and delayed diagnosis and treatment due to insufficient resources particularly in rural and remote areas remains to be a significant problem $[18,21]$.

Cancer mortality and survival are influenced by treatment and timeliness of its initiation. Treatment of breast cancer patients in Western Kazakhstan is carried out in accordance with the standard protocol recommended by the Expert Council of the Republican Health Care Centre from March 01, 2019.

Lobular carcinoma in situ - local and systemic treatments are not indicated, but women who are sick should be closely monitored for breast cancer. Ductal carcinoma in situ - breast-conserving surgery followed by radiation therapy is standard treatment; however, mastectomy may be recommended for extensive or multifocal disease. Stages I and II: early stage of invasion - organ-preserving surgery and radical mastectomy at the request of the patient. Postoperative RT is performed in the classical dose fractionation mode (ROD 2 Gy, SOD 30 Gy) after the operation and systemic therapy. The postoperative area is additionally irradiated at a dose of 12 Gy (2 Gy each). All stage II patients receive adjuvant systemic chemotherapy according to the scheme (CMF, AC, TAC, AC + T, FAC, CAF, FEC, A + CMF).

With + ER tamoxifen for 5 years.

With - ER, chemotherapy.

Patients with a positive Her 2-neu - trastuzumab at $8 \mathrm{mg} / \mathrm{kg}$ on day 1 , every 21 days at $4 \mathrm{mg} / \mathrm{kg}$.

Stage III treatment begins with non-adjuvant chemotherapy courses followed by an assessment of the dynamics. Possible options:

1) when regression $(+)$ of the tumor process is achieved after NAPHT, surgical treatment is indicated, followed by chemoradiation therapy and hormone therapy in the presence of the expression of steroid hormones.

2 ) if there is no effect ( - ) from the courses of NAPHT, it is possible to carry out radiation therapy, followed by surgical treatment. Further, it is recommended to change courses of adjuvant chemotherapy with hormone therapy in the presence of the expression of steroid hormones.

Postoperative RT is performed in the classical dose fractionation mode (ROD 2 Gy, SOD up to an equivalent dose of $60 \mathrm{~Gy})$. Irradiation fields: supraclavicular, axillary, parasternal, chest wall.

Stage IV - palliative chemotherapy or chemoradiation therapy, if necessary, sanitary or simple mastectomy [13].
Our findings suggest that an increase in the proportion of cases diagnosed at an early stage made a relatively small contribution to improving survival. At the same time, the difference in survival of urban and rural areas observed in crude analysis was alleviated by adjustment for stage of cancer suggests that rural women are diagnosed at later stages than their urban counterparts. An increase in the proportion of deaths in the youngest age group should raise serious concerns among local health authorities.

Studies of the associations between histological type of a tumor and survival provide inconsistent results, but many assume that the survival of patients with lobular carcinoma is better than that of patients with other types of cancer [23]. Invasive ductal carcinoma and invasive lobular breast carcinoma (ILC) are the main two pathologically defined groups of malignant breast tumors, which account for $80 \%$ and $15 \%$ of all invasive breast cancers, respectively [18]. Our results show that ductal carcinoma is more common and survival is similar to lobular carcinoma. Our results suggest that that histological type may serve as a prognostic factor for survival if replicated in other studies.

\section{Conclusions}

The incidence of and mortality from breast cancer in West Kazakhstan is lower than in other countries of the European WHO Region. There has been a significant shift in morbidity and mortality towards younger age groups, which may be associated with an increase in screening in recent years. Many cases are still diagnosed in advanced stages. Significant differences in survival were observed only by stage of cancer in multivariable analysis. Increased number of deaths in the youngest age group requires further research into timeliness of diagnostics and the quality of breast cancer treatment in the region. Surprisingly high level of five-year survival in the study area requires further investigation. The results should be interpreted with caution assuming valid data on cancer-specific mortality and non-differential reporting of deaths across the studied characteristics.

\section{Conflicts of Interest}

None declared.

\section{Authors Contribution}

All authors equally contributed to study concept and design. Marzhan A. Aitmagambetova collected the data. All authors equally contributed to data analysis. Marzhan A. Aitmagambetova and Andrey M. Grjibovski drafted the first version of the manuscript. All authors critically evaluated the first draft and commented on it. The final version was approved by all the authors.

Marzhan A. Aitmagambetova - ORCID 0000-0002-0346-5829 Yerbol Zh. Bekmukhambetov - ORCID 0000-0001-8610-8140 Gaziza A. Smagulova - ORCID 0000-0001-7222-620x

Anar B. Tulyayeva - ORCID 0000-0001- 7149-0121

Arip K. Koyshybaev - ORCID0000-0002-6164-8009

Andrey M. Grjibovski - ORCID 0000-0002-5464-0498 


\section{References}

1. Рахимова М. Н., Уразаева С. Т., Уразаев О. Н., Бегалин Т. Б. Эпидемиология рака молочной железы в странах СНГ и Республике Қазахстан (литературный обзор) // West Kazakhstan Medical journal. 2019, T. 61(1). C. 46-55.

Rakhimova M N, Urazayeva S T, Urazayev O N, et al. Breast cancer epidemiology (literature review). West Kazakhstan Medical journal. 2019, 61 (1), pp. 46-55. [In Russian]

2. Унгуряну Т. Н., Гржибовский А. М. Программное обеспечение для статистической обработки данных STATA: введение // Экология человека. 2014, № 1. С. 60-63. doi: 10.33396/1728-0869-2014-1-60-63

Unguryanu T N, Grjibovski A M. Introduction to Stata Software for Statistical Data Analysis. Ekologiya cheloveka (Human Ecology). 2014, 1, pp. 60-63. doi: 10.33396/17280869-2014-1-60-63 [In Russian]

3. Allemani C, Matsuda T, Di Carlo V, et al. Global surveillance of trends in cancer survival 2000-14 (CONCORD-3): analysis of individual records for 37513025 patients diagnosed with one of 18 cancers from 322 populationbased registries in 71 countries. Lancet. 2018, 391 (10125), pp. 1023-1075.

4. Abiltayeva A, Moore M A, Myssayev A, et al. Clinical, histopathological and molecular characteristics of metastatic breast cancer in North-Eastern Kazakhstan:a 10 year retrospective study. Asian Pac J Cancer Prev. 2016, 17, pp. 4797-4802.

5. Bekmukhambetov Y, Imangazina Z, Jarkenov T. Cancer Incidence and Mortality Data in Aktobe, West Kazakhstan, 2000-2010. Asian Pacific Journal of Cancer Prevention. 2015, 16 (6), pp. 2379-2383.

6. Beysebayev E, Bilyalova Z, Kozhakeeva L, et al. Spatial and temporal epidemiological assessment of breast cancer incidence and mortality in Kazakhstan, 1999-2013. Asian Pac J Cancer Prev. 2015, 16 (15), pp. 6795-6798.

7. Bhoo-Pathy N, Yip CH, Hartman $M$, et al. Breast cancer research in Asia: adopt or adapt Western knowledge? Eur J Cancer. 2013, 49, pp. 703-9

8. Cancer Incidence, Mortality and Prevalence Worldwide in 2012. International Agency for Research on Cancer (IARC). Available: http://www.globocan.iarc.fr/ (accessed: 12.04.2014).

9. Chukmaitov A S, Kaidarova D R, Talaeyva S T, et al. Analysis of Delays in Breast Cancer Treatment and Late-Stage Diagnosis in Kazakhstan. Asian Pac J Cancer Prev. 2018, 19 (9), pp. 2519-2525.

10. DeSantis C E, Bray F, Ferlay J, et al. International variation in female breast cancer incidence and mortality rates. Cancer Epidemiol Biomarkers Prev. 2015, 24, pp. 1495-506

11. Ferlay J, Soerjomataram I, Dikshit R, et al. Cancer incidence and mortality worldwide: sources, methods and major patterns in GLOBOCAN 2012. Int J Cancer. 2015, 136, pp. E359-E386.

12. Ferlay J, Colombet $M$, Soerjomataram I, et al. Estimating the global cancer incidence and mortality in 2018: GLOBOCAN sources and methods. Int J Cancer. 2018, 8, pp. $1941-1953$

13. https://diseases.medelement.com/upload/0e42d5a4 b7a0b45c7ae5afbae4b200d8.pdf «Periodic protocols for the diagnosis and treatment of malignant neoplasms».

14. https://erob.eisz.kz/app/win7532 (accessed: 10.12.2020).
15. Igissinov N, Igissinov S, Moore M A, et al. Trends of prevalent cancer incidences in the Aral Sea area of Kazakhstan. Asian Pac J Cancer Prev. 2011, 12, pp. 2299-303.

16. Igissinov N, Toguzbayeva A, Turdaliyeva B, et al. Breast Cancer in Megapolises of Kazakhstan: Epidemiological Assessment of Incidence and Mortality. Iran J Public Health. 2019, 48 (7), pp. 1257-1264

17. Jassem J, Ozmen V, Bacanu F, et al. Delays in diagnosis and treatment of breast cancer: a multinational analysis. Eur J Public Health. 2014, 24, pp. 761-767.

18. Kim Y, Yoo K Y, Goodman M T. Differences in Incidence, Mortality and Survival of Breast Cancer by Regions and Countries in Asia and Contributing Factors. Asian Pacific Journal of Cancer Prevention. 2015, 16 (7), pp. 2857-2870.

19. La Rosa F, Patavino V M, Epifani A C, Petrinelli A M, et al. Ten-year survival and age at diagnosis of women with breast cancer from a population-based study in Umbria, Italy. Tumori. 1996, 82, pp. 441-443.

20. Moore M A, Eser S, Igisinov N, et al.Cancer epidemiology and control in north-western and central asia past, present and future. Asian Pac J Cancer Prev. 2010, 11 , pp. 17-32.

21. Nematolahi S, Ayatollahi S M T. A comparison of breast cancer survival among young, middle-aged, and elderly patients in southern Iran using Cox and empirical Bayesian additive hazard models. Epidemiol Health. 2017, 39, e2017043.

22. Paluch-Shimon S, Pagani O, Partridge A H, et al. WHO. Breast cancer: Prevention and control. WHO; 2017. Available at: http://www.who.int/cancer/detection/breast cancer/en/, ESO-ESMO 3rd international consensus guidelines for breast cancer in young women (BCY3) Breast. 2017, 35, pp. 203-217.

23. Pestalozzi B C, Zahrieh D, Mallon E, Gusterson B A, et al. Distinct clinical and prognostic features of infiltrating lobular carcinoma of the breast: Combined results of 15 International Breast Cancer Study Group clinical trials. J ClinOncol. 2008, 26, pp. 3006-3014.

24. Sung H, Ferlay J, Siegel R L, Laversanne M. Global cancer statistics 2020: GLOBOCAN estimates of incidence and mortality worldwide for 36 cancers in 185 countries. CA Cancer J Clin. 2021, 71, pp. 209-249. https://doi. org/10.3322/caac. 21660

25. The Global Cancer Observatory - All Rights Reserved - May, 2019 http://gco.iarc.fr/today/data/factsheets/ cancers/20-Breast-fact-sheet.pdf 6

26. Youlden D R, Cramb S M, Yip C H, et al. Incidence and mortality of female breast cancer in the Asia-Pacific region. Cancer Biol Med. 2014, 11 (2), pp. 101-115.

27. Vakili M, Pirdehghan A, Adimi M, et al. Epidemiology and trend of cancer in yazd, a central province of iran, 20052009. J Res Health Sci. 2014, 14, pp. 210-213.

28. WHO. World health organization. Cancer country profiles: Kazakhstan. 2014. Available at: http://www.who. int/cancer/country-profiles/kaz_en.pdf?ua =1 (accessed on July 10, 2017)

\section{Contact details:}

Marzhan Aytmagambetova - PhD candidate, West

Kazakhstan Marat Ospanov Medical University 68 Maresyev St., Aktobe 030019, Kazakhstan E-mail: inzhumarzhan90@mail.ru 